\title{
ANALISIS SELF EFFICACY MAHASISWA MELALUI KEMAMPUAN PRESENTASI DI KELAS
}

\author{
Diana Hernawati ${ }^{1,2)}$, Mohamad Amin ${ }^{1)}$ \\ 1) Program Studi Pendidikan Biologi, Pascasarjana, Universitas Negeri Malang \\ Jl. Semarang No. 5, Malang \\ 2) Program Studi Pendidikan Biologi, FKIP, Universitas Siliwangi \\ Jl. Siliwangi No. 24 Tasikmalaya \\ Email: hernawatibiologi@unsil.ac.id
}

\begin{abstract}
Abstrak. Presentasi adalah sebuah komunikasi yang membuat orang dapat berpikir logis, tepat dan mempunyai argumen yang kuat. Studi ini menganalisis mengenai self efficacy mahasiswa melalui kemampuan presentasi di kelas. Analisis ini didasarkan pada data empiris yang dikumpulkan berdasarkan hasil observasi dari 160 partisipan yaitu mahasiswa pendidikan Biologi di Universitas Siliwangi Tasikmalaya. Selanjutnya data yang diperoleh diolah dengan menggunakan statistik deskriptif. Hasil penelitian secara umum menunjukkan bahwa mahasiswa cukup terbiasa dengan diskusi presentasi di kelas berdasarkanefisiensi dan efektivitas dalam presentasi dengan rata-rata nilai di bawah $75 \%$, pembahasan masalah yang dilakukan berdasar kajian teoritis/praktis, rasional, dan tanggung jawabrata-rata di bawah $75 \%$, berjalan multi arahrata-rata di atas $75 \%$, semua anggota terlibat secara aktifrata-rata di atas $75 \%$ dan penyajian materi yang menarik (video, bagan, gambar, dll) rata-rata masih di bawah $75 \%$. Berdasarkan hal tersebut tergambarkan bahwa beberapa kemampuan mahasiswa cukup terbiasa dengan proses pembelajaran melalui presentasi di kelas. Beberapa kemampuan lainnya masih perlu untuk dilatihkan sehingga kemampuanmahasiswa dalam presentasi harapannya dapat lebih meningkat.
\end{abstract}

Kata kunci: Kemampuan presentasi, Mahasiswa, Self efficacy

Abstract. Presentation is one of the communication skills enabling the speakers to be able to think logically, accurately and firmly. This study was aimed at analyzing the students' selfefficacy through their classroom presentations. The analysis was anchored on the empirical data obtained through observation results of 160 participants coming from the Biology Education Department, Siliwangi University, Tasikmalaya. In addition, the obtained data were analyzed and computed with descriptive statistical framework. The findings generally revealed that the students were accustomed to performing classroom presentations. This was supported by the evidence showing that the efficiency and effectiveness of classroom presentations were under $75 \%$ percentages of the total averages. Besides, the problem discussions were conducted with theoretical, practical, rationalistic and responsible attitudes, particularly under $75 \%$ percentages of the total averages. Also, the classroom presentations ran bi-directionally beyond $75 \%$ percentages of the total averages. Likewise, each member of presenters was actively engaged in classroom presentations with $75 \%$ percentages beyond the total averages. Additionally, the ability to present the materials attractively (e.g. videos, diagrams, pictures, etc.) was still under $75 \%$ percentages of the total averages. For these reasons, the students were accustomed to presenting the learning materials in the classrooms represented by their well-established presentation skills. However, a few skills should be taken into account through intensive trainings because they were still under the expected results.

Keywords: Presentation skills, Biology Department Students, self-efficacy 
PENDAHULUAN

Pendidikan merupakan suatu hal untuk menjamin kelangsungan hidup dan merupakan modal besar dalam menghadapi persaingan. Pendidikan merupakan salah satu proses untuk menambah ilmu pengetahuan, meningkatkan kreatifitas dan memperbaiki kepribadian seorang manusia. Pendidikan juga diperlukan untuk mendukung terciptanya manusia yang cerdas serta mampu bersaing di era globalisasi. Akan tetapi kenyataannya sistempendidikan yang ada masih banyak mengalami masalah. Fitriani (2013) mengemukakan bahwa permasalahan besar yang menghadang dunia pendidikan adalah masih rendahnya mutu dan relevansi pendidikan. Hal yang mendasar dan sering terjadi di lapangan adalah rendahnya interaksi antar dosen dan mahasiswa maupun antar sesama mahasiswa yang mengakibatkan terjadi komunikasi satu arah dan tidak munculnya keaktifan mahasiswa dalam proses pembelajaran.

Banyak upaya yang pemerintah lakukan untuk pembaruan-pembaruan dalam dunia pendidikan. Penyempurnaan pola pikir dari pembelajaran yang berpusat pada pendidik diubah menjadi pembelajaran berpusat pada peserta didik, pembelajaran satu arah (interaksi pendidik dengan peserta didik) menjadi pembelajaran interaktif, pola pembelajaran pasif menjadi pembelajaran aktif, pola belajar sendiri menjadi belajar kelompok atau tim, pola pembelajaran alat tunggal menjadi pembelajaran alat multimedia, (Hosnan, 2014). Tentunya semuanya untuk mewujudkan suatu pendidikan yang berkualitas dan dapat menciptakan sumber daya manusia yang lebih baik.

Sumber daya manusia yang baik diawali dari titik yang paling rendah dalam konteks pendidikan formal. Dalam hal ini tentunya pendidikan yang tidak akan lepas dari yang namanya pembelajaran. Pembelajaran pada hakikatnya adalah usaha sadar dari seorang pendidik untuk membelajarkan peserta didik (mengarahkan interaksi peserta didik dengan sumber belajar lainnya) dalam rangka mencapai capaian pembelajaran. Selain itu proses pembelajaran juga dipengaruhi oleh perkembangan peserta didik. Perkembangan peserta didik adalah perkembangan seluruh aspek kepribadiannya. Akan tetapi tempo dan irama perkembangan masing-masing peserta didik pada setiap aspek tidak selalu sama. Dengan demikian setiap pendidik harus melaksanakan pembelajaran secara kreatif dan inovatif sesuai dengan karakteristik mahasiswa dan kondisi serta kebutuhannya.Menghadapi perubahan paradigma di atas Amin (2015) menyatakan bahwa peserta didik perlu membekali diri dengan upaya sadar akan keterampilanketerampilan yang diperlukannya.

Beberapa keterampilan tersebut untuk menunjang dan menciptakan pembelajaran yang aktif, kreatif, efektif, 
danmenyenangkan.Salah satunya yang artian efikasi diri (sel fefficacy) tidak selalu dapatmenunjang hal tersebut adalah menggambarkan kemampuan yang membiasakan peserta didik melakukan sebenarnya, tetapi terkait dengan keyakinan diskusi interaktif. Diskusi merupakan salah yang dimiliki individu Bandura, 1986). satu bentuk kegiatan wicara. Dengan Menurut Bandura dalam Santrock (2008) berdiskusi mahasiswa dapat memperluas bahwa self efficacy seseorang dapat pengetahuan serta memperoleh banyak menguasai situasi dan memproduksi hal pengalaman-pengalaman. Diskusi adalah positif. Sel fefficacy merupakan faktor yang suatu pertukaran pikiran, gagasan, pendapat mempengaruhi prestasi peserta didik. Self antara dua orang atau lebih secara lisan efficacy adalah sebuah factor yang sangat dengan tujuan mencari kesepakatan atau penting dalam menentukan apakah peserta kesepahaman gagasan atau pendapat. Sementara presentasi adalah proses perpindahan informasi, gagasan, emosi, dan sebagainya dengan menggunakan simbolsimbol, kata-kata, gambar, grafis, angka, dll dari seorang pembicara pada audiens dengan maksud tertentu (Lubis (2016); Andrianto (2008); Sukaedi (2017); Purwaningsih (2009).Terkadang kemampuan diri untuk dapat berkomunikasi dengan baik terhalang oleh faktor keyakinan diri yang rendah. Keyakinan diri biasa dikenal dengan istilah self efficacy.

Bandura (1997) mendefinisikan bahwa efikasi diri (self-efficacy) merupakan persepsi individu akan keyakinan kemampuannya untuk melakukan tindakan yang diharapkan. Konsep dasar teori efikasi diri (self efficacy) adalah keyakinan dari setiap individu dengan kemampuan untuk mengontrol pikiran, perasaan dan perilakunnya. Efikasi diri (self efficacy) merupakan masalah persepsi subyektif dalam didik berprestasi atau tidak, seseorang yang memiliki efikasi diri tinggi akan memiliki satu keyakinan bahwa "saya dapat", sedangkan seseorang yang mempunyai efikasi diri rendah akan memiliki satu keyakinan bahwa "saya tidak dapat". Dalam arti lain self efficacy dapat menimbulkan efek yang beragam dalam bebagai setting prestasi (Maddux \& Winne di kutip dari Santrock, 2009; Pajares, 1996; Schunk, 2012).

Untuk itu membiasakan mahasiswa mengasah kemampuan presentasi dengan didukung self eficacy, perlu dibiasakan kepada mahasiawa dalam proses pembelajaran untuk hasil lebih maksimal.Tujuan dilakukannya penelitian ini dengan maksud untuk mendeskripsikan bagaimana analisis self efficacy mahasiswamelalui kemampuan presentasi di kelas. Temuan ini diharapkan dapat dijadikan referensi dalam memberdayakan kemampuan mahasiswa khususnya dalam hal presentasi di kelas dengan self efficacy yang tinggi. 


\section{METODE}

Sebanyak 160 partisipan mahasiswa yang mengikuti perkuliahan zoologi pada semester 6 dijadikan sebagai subjek penelitian. Sampel diambil dengan menggunakan teknik sampling jenuh, dimana semua populasi dijadikan sebagai sampel penelitian. Metode penelitian yang digunakan dengan teknik observasi untuk menganalisis self efficacy mahasiswa melalui hasil presentasi di kelas pada mata kuliah zoologi invertebrata. Selanjutnya data yang diperoleh diolah dengan menggunakan statistik deskriptif kualitatif.

\section{HASIL DAN PEMBAHASAN}

Hasil penelitian berupa deskripsi umum analisis self efficacy mahasiswamelalui kemampuan presentasi di kelas secara umum dapat digambarkan hasilnya pada Gambar 1.

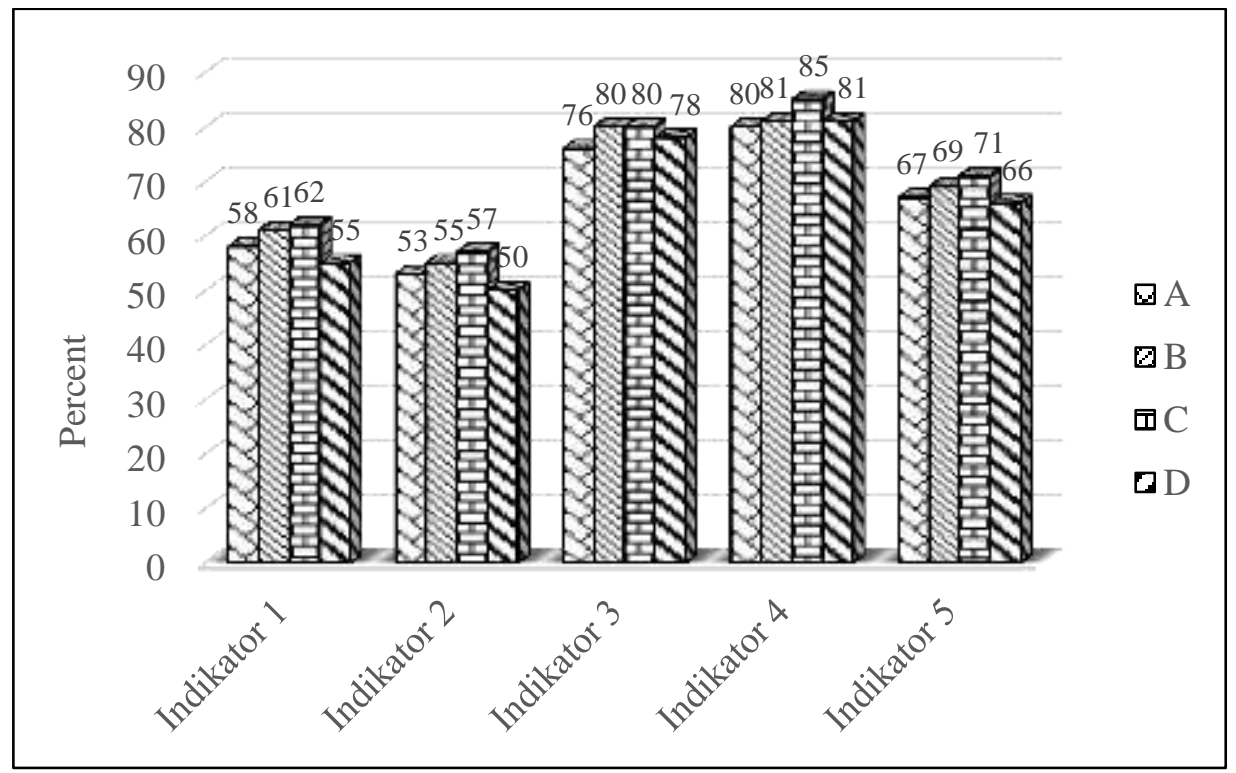

Gambar 1. Grafik perbedaan kemampuan presentasi mahasiswa tentang pembelajaran Zoologi Invertebrata

Konsep belajar merupakan suatu motivasi dan menciptakan iklim belajar yang kegiatan yang dilakukan secara sadar dan harmonis, kondusif, menyenangkan serta terencana yang mengarah pada pencapaian mampu memberi semangat kepada peserta tujuan dari kegiatan belajar yang sudah didik. Hal ini tergambarkan dalam Gambar 1 dirumuskan dan diterapkan sebelumnya, bahwa pada umumnya rata-rata mahasiswa menjadi salah satu hal yang perlu untuk dalam prinsip efisiensi dan efektivitas dalam diperhatikan juga.Tercapainya tujuan belajar presentasi masih di bawah $75 \%$, pembahasan seperti yang diterapkan dalam kegiatan masalah yang dilakukan berdasar kajian belajar mengajar merupakan suatu gambaran teoritis/praktis, rasional, dan tanggung jawab keberhasilan pendidik yang mampu memberi di bawah $75 \%$, berjalan multi arah di atas 
$75 \%$, semua anggota terlibat secara aktifdi atas $75 \%$ dan penyajian materi yang menarik (video, bagan, gambar, dll) masih di bawah $75 \%$.

Prinsip efisiensi dan efektivitas dalam presentasi, pembahasan masalah yang dilakukan berdasar kajian teoritis/praktis, rasional, dan tanggung jawabdan penyajian materi yang menarik (video, bagan, gambar, dll) yang rata-rata masih di bawah $75 \%$ menunjukkan perlunya latihan yang lebih intensif lagi terkait hal-hal tersebut. Beberapa hal yang menjadi pendukung kemampuan tersebut diantaranya kemampuan komunikasi. Kemampuan ini berkaitan dengan kemampuan mahasiswa dalam menyampaikan laporan, gagasan, dan ide, baik lisan maupun tulisan. Menurut Joyce (2000) mengatakan bahwa kemampuan berkomunikasi ilmiah berkorespondensi positif dalam tingkat pemahaman konsep. Penggunaan presentasi di depan kelas dan diskusi kelompok dalam proses pembelajaran dapat prioritas yang baik dan membawa hasil yang maksimal.

Presentasi adalah sebentuk komunikasi, yang dilakukan secara terpadu lewat suara, gambar, dan bahasa tubuh. Komunikasi yang sukses terjadi ketika audiens menerima dan memahami sebuahpesan persis sama dengan apa yang dimaksudkan oleh komunikator. Hal ini bisatercapai jika komunikator menggunakan media yang tepat, dengan carapenyampaian yang tepat, dan pada waktu yang tepat. Namun realitas dilapanganmengungkapkan ternyata tidak mungkin sebuah pesan, atau gagasan, yangdisampaikan oleh pemberi pesan diterima dengan sempurna 100 persen oleh penerima. Dalam proses penyampaian, informasi sedikit banyak akan mengalamidistorsi informasi. Disinilah seorang komunikator harus berupaya meminimalisirdistorsi informasi tersebut, sehingga pesan/informasi sukses diterima dengan baik oleh pendengarnya (Rahmat, 2016).

Selama ini presentasi sering dianggap remeh atau mudah dan kurang mendapatkan respon yang baik dari mahasiswa, tetapi dengan penguatan self effcacy yang tinggi diharapkan perhatian dan konsekuensi mahasiswa jauh lebih baik dan terarah serta dengan mudah menyerap materi yang diberikan oleh dosen. Keterlibatan mahasiswa secara langsung dalam kegiatan pembelajaran juga terjamin dengan penerapan teknik ini, sehingga mahasiswa tidak hanya belajar konsep secara teoritis tetapi mencakup juga aspek implementasi. Presentasi dan diskusi kelompok membantu dosen untuk berkembang secara profesional, memperbaiki pembelajaran, memotivasi untuk lebih inovatif dalam pembelajaran.Rahmat (2016) dan Rifa (2012) mengemukakan kelebihan presentasi adalah pembicara dapat menjelaskan secara sistimatis seluruh materi yang akan 
disampaikan dengan kelas sepenuhnya dikuasai oleh pembicara.

Apabila dilihat dalam perkembangan kognitif, seseorang akan mulai berpikir rasional tentang banyak hal, termasuk semua hal yang terjadi dan berkaitan dengan dirinya. Pengetahuan individu tentang diri, perpaduan antara perasaan, sikap, dan persepsi bawah sadar ataupun sadar dinamakan sebagai konsep diri (Potter \& Perry, 2005). Hardiknas (2016) menyebutkan bahwa konsep diri penting artinya karena individu dapat memandang diri dan dunianya, mempengaruhi tidak hanya individu berperilaku, tetapi juga tingkat kepuasan yang diperoleh dalam hidupnya. Setiap individu pasti memiliki konsep diri, tetapi mereka tidak tahu apakah konsep diri yang dimiliki itu negatif atau positif. Mahasiswa yang memiliki konsep diri positif ia akan memiliki dorongan mandiri lebih baik, ia dapat mengenal serta memahami dirinya sendiri sehingga dapat berperilaku efektif dalam berbagai situasi. Konsep diri positif bukanlah suatu kebanggaan yang besar tentang diri tetapi berupa penerimaan diri. Mahasiswa yang memiliki konsep diri positif dapat memahami dan menerima sejumlah faktor yang sangat bermacammacam tentang dirinya sendiri.

Dalam hal ini mahasiswa dapat menerima dirinya secara apa adanya dan akan mampu mengintrospeksi diri atau lebih mengenal dirinya, serta kelemahan dan kelebihan yang dimiliki. Namun mahasiswa yang memiliki konsep diri negatif, ia tidak memiliki perasaan kestabilan dan keutuhan diri, juga tidak mengenal diri baik dari segi kelebihan maupun kekurangannya atau sesuatu yang ia hargai dalam hidupnya. Adanya konsep diri yang baik pada seseorang, akan berpengaruh kepada self efficacy untuk menyelesaikan suatu masalah dengan baik pula, temasuk keyakinan terhadap hasil belajarnya. Self efficacy untuk meningkatkan hasil belajar yang dimiliki setiap orang berbeda-beda. Faktor yang berkaitan dengan keberanian dan self efficacy akan kemampuan yang dimiliki individu dapat diasah dan dilatih melalui pembiasaan diri. Hal ini menjadikan self efficacy atau keyakinan individu mengenai kemampuan dirinya untuk mengorganisasi, melakukan suatu tugas, dapat tercapai sesuai tujuan dan harapan.

Self efficacy mengacu pada persepsi tentang kemampuan individu untuk mengorganisasi dan mengimplementasi tindakan untuk menampilkan kecakapan tertentu (Bandura, 1986).

Komponen lain presentasi yang rataratanya di atas $75 \%$ adalah proses presentasi yang berjalan multi arah dan semua anggota terlibat secara aktif. Kemampuan ini menunjukkan kemampuan peserta didikdalam mengembangkan dan merangsang keterlibatan peserta didik lainnya lebih baik. Proses pembelajaran 
seperti inimembiasakan peserta didik belajar proses untuk menjawab pertanyaan dan memecahkan masalah. Kondisi seperti ini menunjukkan adanya keterkaitanan antara keyakinan diri dengan kecemasan presentasi.

Menurut Andrianto (2008) jika komunikasi dan keyakinannya tinggi maka kecemasan presentasinya rendah. Begitu juga sebaliknya jika ketrampilan komunikasi dan keyakinan dirinya rendah maka kecemasan presentasinya tinggi. Self efficacy merupakan kepercayaan atau keyakinan individu mengenai kemampuan dirinya untuk mengorganisasi, melakukan suatu tugas, mencapai suatu tujuan, menghasilkan sesuatu dan mengimplementasikan tindakan untuk menampilkan kecakapan tertentu untuk mencapai hasil tertentu.

Hubungan di atas dapat dikatakan juga bahwa individu yang mempunyai efikasi diri tinggi akan memilih melakukan usaha lebih besar dan lebih pantang menyerah. Efikasidiri mempunyai peran penting pada pengaturan motivasi seseorang. Putri (2016); Rajawanti (2014) berpendapat bahwa seseorang yang yakin akan kemampuannya memiliki motivasi tinggi dan berusaha untuk sukses. Dapat dikatakan individu yang memiliki efikasi diri tinggi akan meningkatkan usahanya untuk mengatasi tantangan dengan menunjukkan usaha dan keberadaan diri yang positif. Hal tersebut memerlukan perasaan keunggulan pribadi (senseof personal efficacy). Berikut adalah tiga pertimbangan yang dikemukakan oleh Pervin dalam BartSmet (1994) bahwa efikasi diri (sel fefficacy) adalah penengah antara tujuan dengan sasaran. Pertimbangan yang dibuat adalah: (a) harapan akan hasil dan perilaku (outcomeexpectancy), (b) harapan dapat membentuk perilaku secara tepat (efficacyexpectancy), dan (c) nilaihasil (outcomevalue).

\section{SIMPULAN DAN SARAN}

Berdasarkan analisis data yang diperoleh tergambarkan beberapa kemampuan mahasiswa sudah cukup terbiasa dengan proses pembelajaran melalui presentasi di kelas. Beberapa kemampuan lainnya masih perlu untuk dilatihkan sehingga kemampuanmahasiswa tersebut masih kurang. Hal ini berkaitan dengan self efficacy yang mempunyai peran penting pada pengaturan motivasi seseorang dan prestasi mahasiswa.

\section{DAFTAR PUSTAKA}

Amin, M. 2015. Biologi sebagai Sumber Belajar untuk Generasi Mendatang yang Berintegritas Dan Berperadaban Tinggi. Pidato Pengukuhan Jabatan Guru Besar. Fakultas Matematika dan Ilmu Pengetahuan Alam.Universitas Negeri Malang. Kemristekdikti.

Andrianto, B. H. I. M. O. (2008). Kecemasan Presentasi ditinjau dari Ketrampilan Komunikasi dan Kepercayaan Diri pada Mahasiswa. Skripsi Tidak dipublikasikan Universitas Islam Indonesia Yogyakarta. 
Bandura, A. 1986. Social Foundations of Thought and Action: A Social Cognitive Theory. New Jersey: Prentice Hall, Inc. Engglewood Cliffs.

Bandura, A. 1997. Self Efficacy: The Exercise of Control. New York: W. H. Freeman Company.

BartSmet.1994. PsikologiKesehatan. Jakarta: PT. Grasindo.

Fitriani, D. U. L. I. S. (2010). Meningkatkan Kemampuan Komunikasi Matematik Siswa SMP dengan Pembelajaran Student Facilitator and Explaining. Jurnal PendidikanMatematika, 2 (1).

Hardiknas, Y. S., Nursalim, M., \& Si, M. (2016). Penerapan Bimbingan Kelompok Teknik Diskusi Untuk Meningkatkan Konsep Diri Positif Siswa SMP Negeri 2 Manganti Gresik. Jurnal Mahasiswa Teknologi Pendidikan, 6 (3).

Hosnan, M. 2014. Pendekatan Saintifik dan Konstektual dalam Pembelajaran Abad 21. Bogor: Ghalia Indonesia.

Joyce B., Weil M., dan Calhoun E. 2000. Model of Teaching, Sixth edition. Boston: Allyn and Bacon.

Lubis, A. M. (2016). Pengaruh Penerapan Layanan Bimbingan Kelompok Teknik Diskusi dalam Mengurangi Kesulitan Belajar Matematikadi SMA N 11 Medan TA 2015/2016 (Doctoral dissertation, UNIMED).

Pajares, F. 1996. Self-efficacy Belief in Achievement Settings. Review of Educational Research, 66: 543-578.

Potter, P.A. \& Perry, A.G. 2005. Buku Ajar Fundamental Keperawatan. Edisi 4. Volume 1. Jakarta: EGC.

Purwaningsih, S. (2009). Peningkatan Prestasi Belajar Biologi Siswa Kelas
X. 1 SMA N 2 Salatiga melalui Metode Proyek dengan Penilaian Presentasi dan Poster. Lembaran Ilmu Kependidikan, 38(1).

Putri, A. N., Nursalim, M., \& Si, M. (2016). Penerapan Layanan Bimbingan BimbinganKelompok Teknik Diskusi Kelompok untuk Meningkatkan Motivasi Belajar pada Siswa Kelas VIII SMP Negeri 2 Sidoarjo. Jurnal BK UNESA, 6(3).

Ragawanti, E. (2014). Pengaruh On the job training dan Off The Job Training terhadap Kinerja Karyawan (Studi pada Karyawan Tetap PR. Sejahtera Abadi). Jurnal Administrasi Bisnis, $8(2)$.

Rahmat, M. M. (2016). Peningkatan Prestasi Belajar PAI Melalui Metode Diskusi dan Presentasi Power Point bagi Peserta Didik Kelas VII F SMP F SMP Negeri 2 Banjarnegara. AL-QALAM, $6(1)$.

Rifa, A. I. (2012). Efektivitas Media Pembelajaran CD e-learning SMA Matematika Dilengkapi Metode Diskusi dan Presentasi terhadap Minat Belajar dan Kemampuan Berpikir Kritis Peserta Didik SMA (Studi Eksperimen di MAN LAB UIN Yogyakarta) (Doctoral dissertation, UIN Sunan Kalijaga).

Schunk, DH. 2012. Learning Theories an Educational Perspective. Yogyakarta: Pustaka Pelajar.

Sukaedi, S. (2017). Peningkatan Prestasi Belajar Pendidikan Kewarganegaraan dengan Metode Presentasi dan Diskusi Kelompok(Siswa Kelas III SDN Candijati 01 Arjasa). Pancaran Pendidikan, 5(4), 21-30.

Santrock, W. J. 2009. Educational Psychology. Jakarta: Salemba Humanika. 